\title{
Nerve Damage
}

National Cancer Institute

\section{Source}

National Cancer Institute. Nerve Damage. NCI Thesaurus. Code C50669.

Injury to nervous tissue. 